\title{
Isotopic composition of soil, vegetation or cattle hair no suitable indicator of nitrogen balances in permanent pasture
}

\author{
Nicole Wrage • Frank Küchenmeister • \\ Johannes Isselstein
}

Received: 9 August 2010/ Accepted: 7 January 2011/Published online: 18 January 2011

(C) The Author(s) 2011. This article is published with open access at Springerlink.com

\begin{abstract}
Stable isotope signatures of cattle tail switch hair or meadow vegetation have been found to be related to nitrogen $(\mathrm{N})$ surpluses of whole farms and of meadows, respectively. Permanent pastures are more patchy in terms of nutrient inputs and outputs and $\mathrm{N}$ balances for the whole plot do not necessarily give correct impressions of losses. We here investigated correlations between isotopic signatures and $\mathrm{N}$ balances calculated for different spatial and temporal scales in permanent pastures. $\mathrm{N}$ concentrations and $\delta^{15} \mathrm{~N}$ values of cattle tail switch hair, vegetation and soil samples were measured in an experiment with different grazing intensities started in 2002. Results were compared to soil surface balances calculated for the whole plot or for plot areas affected by either dung, urine, grazing without excreta input, or the pasture area without dung pats. There were no significant correlations between plant or cattle hair isotopic signatures and any of the balances. $\mathrm{N}$ fixation probably influenced vegetation signatures, making the isotopic values less dependent on soil and more on atmospheric $\mathrm{N}$. The cattle preferred short mixed vegetation with more legume biomass, which also influenced the ${ }^{15} \mathrm{~N}$ values of their hair. The ${ }^{15} \mathrm{~N}$ signatures of soil samples were the best
\end{abstract}

N. Wrage $(\bowtie) \cdot$ F. Küchenmeister $\cdot$ J. Isselstein Institute of Grassland Science, Department of Crop Sciences, University of Goettingen, von-Siebold-Str. 8, 37075 Goettingen, Germany

e-mail: nwrage@uni-goettingen.de indicators of partial $\mathrm{N}$ balances in these heterogeneous pastures, probably because soil values are most directly influenced by $\mathrm{N}$ inputs and outputs. Still, soil signatures only explained between 15 and $35 \%$ of the variation in balance results. Thus, none of the tested parameters can be used as a reliable indicator of $\mathrm{N}$ balance results in this heterogeneous system with small differences in budgets among treatments and potentially small plot-scale $\mathrm{N}$ losses.

Keywords Nitrogen losses $\cdot{ }^{15} \mathrm{~N} \cdot$ Cattle switch hair · Handpluck sample - Environmental indicator

\section{Introduction}

Nitrogen $(\mathrm{N})$ pools in grassland soils are affected by a range of processes. Some of these may cause $\mathrm{N}$ losses beyond the system boundaries. Such losses have implications for the grassland system itself, but also for its environment, e.g. due to the emission of the greenhouse gas nitrous oxide (Bouwman 1990; IPCC 2001), eutrophication caused by trapping of volatilised ammonia (Oenema et al. 2005) or water contamination by nitrate leaching (Decau et al. 2004).

So far, $\mathrm{N}$ budgets have been used widely for studying $\mathrm{N}$ surpluses and potential losses, usually farm gate or soil surface balances (e.g. Ball et al. 1979; van Beek et al. 2003). Where $\mathrm{N}$ inputs exceed $\mathrm{N}$ outputs, surpluses are assumed to result in $\mathrm{N}$ accumulation in the soil and/or in increased $\mathrm{N}$ 
transfer to the environment. A short-coming of these balancing methods is the assumption of a homogeneous spread of inputs and outputs over the area. This assumption does not hold in pastures, especially not in permanent pastures where animals remain in the same field throughout the grazing season. There, a gradient can be found from very large $\mathrm{N}$ input at excreta patches to $\mathrm{N}$ demand in purely grazed areas that have not received excreta for some time (Auerswald et al. 2010; Franzluebbers et al. 2000; Petersen et al. 1956). At excreta patches, $\mathrm{N}$ losses can be substantial (Saarijärvi et al. 2006; Yamulki et al. 2000) although no N surplus is shown at a plot-scale balance of $\mathrm{N}$ inputs and agronomic outputs.

The measurement of stable isotope signatures of $\mathrm{N}$ might provide a better indication of $\mathrm{N}$ surpluses and losses in such heterogeneous permanent pasture systems. ${ }^{15} \mathrm{~N}$ signatures have been suggested as indicators of the magnitude of $\mathrm{N}$ surpluses (and thus potential $\mathrm{N}$ losses) in different grassland-based production systems (e.g. Bedard-Haughn et al. 2003). Especially gaseous $\mathrm{N}$ losses are related with a large fractionation. Thus, ammonia volatilisation has been found to cause enrichment of remaining soil $\mathrm{N}$ in grasslands with ${ }^{15} \mathrm{~N}$ (Frank et al. 1995). Nitrous oxide produced during nitrification or denitrification is also depleted in ${ }^{15} \mathrm{~N}$ relative to its substrate (Webster and Hopkins 1996; Yoshida 1988), unless it is further reduced to $\mathrm{N}_{2}$, leading to an enrichment of nitrous oxide and depletion of $\mathrm{N}_{2}$. Nitrate leaching is not supposed to lead to fractionation, but if the nitrate is produced by fractionating processes, like nitrification, it can still lead to the loss of depleted $\mathrm{N}$ (Vitousek et al. 1989).

Thus, as most processes leading to losses of $\mathrm{N}$ fractionate against ${ }^{15} \mathrm{~N}$, nitrogen surpluses leading to larger losses result in an enrichment of the grassland system with ${ }^{15} \mathrm{~N}$. Schwertl et al. (2005) tried using the $\mathrm{N}$ isotopic composition of cattle tail switch hair as ecological fingerprints of $\mathrm{N}$ balance components of organic and conventional dairy and meat farms. The advantage of using hair signatures is that over the length of the hair, information is stored about the fodder taken up at different times. Thus, as several segments of a piece of hair are analysed, information is gained about uptake back in time. Schwertl et al. (2005) found a positive correlation between the ${ }^{15} \mathrm{~N}$ signature of the hair and the $\mathrm{N}$ surplus of farm gate balances. In another study, the $\mathrm{N}$ isotopic signature in plant and soil samples in mown grassland was found to reflect soil surface balances of $\mathrm{N}$ : the larger the $\mathrm{N}$ surplus, the more enriched were the samples (Watzka et al. 2006). In all these cases, the influences of the management are integrated in the stable isotope composition of the samples, which are stable over time (with some seasonal variation) if the management is stable (e.g. Neilson et al. 1998; Schnyder et al. 2010; Wittmer et al. 2010).

So far, correlations between $\mathrm{N}$ balances and ${ }^{15} \mathrm{~N}$ signatures have not been studied in permanent pastures. In this study, we have investigated the ${ }^{15} \mathrm{~N}$ signatures of soil, vegetation samples and cattle tail switch hair of permanent pastures differing in stocking rate. These were compared with outcomes of $\mathrm{N}$ soil surface balances calculated either for the whole plot or for areas affected by dung pats, urine patches, pure grazing without excreta input or for the plot area without dung pats (including areas with urine patches and without excretal input). We hypothesised that the ${ }^{15} \mathrm{~N}$ signatures of small scale soil or vegetation samples are better indicators of $\mathrm{N}$ surpluses in extensive pasture systems than those of animal hair, since they may give an idea of the heterogeneity and thus of local $\mathrm{N}$ surpluses. They should correlate with partial $\mathrm{N}$ balances, while cattle tail switch hair ${ }^{15} \mathrm{~N}$ signatures are expected to correlate better with whole plot balances or those for areas excluding dung pats, as that is where the animals feed.

\section{Materials and methods}

Site and general set-up

This study was carried out on a heterogeneous permanent pasture at the experimental farm Relliehausen of the University of Goettingen, in the Solling uplands $40 \mathrm{~km}$ northwest of Goettingen (51 $46^{\prime} 56^{\prime \prime}$ $\mathrm{N} 9^{\circ} 42^{\prime} 10^{\prime \prime} \mathrm{E}, 180-230 \mathrm{~m}$ above mean sea level). The grassland was visually assessed as a moderately species-rich Lolio-Cynosuretum. The soil is a pelosol-brown earth with a $\mathrm{pH}$ of 6.3. For further site information, see Isselstein et al. (2007) and Sahin Demirbag et al. (2009).

In 2002, three grazing treatments with Simmental cattle were established in triplicate in a randomised block design with a paddock size of 1.0 ha: 
(1) Moderate stocking ( $\mathrm{MC}$, target compressed sward height $[\mathrm{CSH}]$ of $6 \mathrm{~cm}$ ),

(2) Lenient stocking (LC, target CSH of $12 \mathrm{~cm}$ ),

(3) Very lenient stocking (VLC, target $\mathrm{CSH}$ of $18 \mathrm{~cm}$ ). Until 2005, treatment VLC was grazed by German Angus cattle to a CSH of $12 \mathrm{~cm}$.

To reach these target sward heights, there were on average $1.3 \pm 0.2,0.7 \pm 0.2$ and $0.5 \pm 0.04 \mathrm{LU}$ $\mathrm{ha}^{-1} \mathrm{a}^{-1}$ on MC, LC and VLC, respectively (averaged over 2006 and 2007; LU: livestock unit of $600 \mathrm{~kg}$. The data is equal to $3.1 \pm 0.5,1.9 \pm 0.3$ and $1.1 \pm 0.1 \mathrm{LU} \mathrm{ha}^{-1}$ during the grazing season for $\mathrm{MC}$, LC and VLC, respectively). The CSH was measured weekly with a rising plate meter (Castle 1976; Correll et al. 2003) and the stocking density adjusted accordingly. The grazing season lasted from May to October, usually interrupted by intervals in July or August when the animals had to be removed from the plots due to insufficient sward productivity.

Sampling and isotope analyses

Soil was sampled in the end of May and July 2006 $(0-10 \mathrm{~cm}$, diameter $2 \mathrm{~cm})$, i.e. after animals had been on the plots for 3 and 7 weeks, respectively. These dates were chosen to check for some seasonal influences on the results, e.g. due to more opportunity for $\mathrm{N}$ losses at the later date. Per plot, three samples were taken, consisting of 20 subsamples from a longitudinal transect of the plots. This scheme was adopted as a compromise between needs for representative sampling and financial constraints. The soil was homogenised, cleared of plant biomass and stones, dried at $105^{\circ} \mathrm{C}$ and sieved $(2 \mathrm{~mm})$.

Plant samples were taken in July 2006 as handpluck samples (HPS) of the upper third of the vegetation to simulate cattle bites (Wade et al. 1989). Per plot, four pooled samples (approximately $200 \mathrm{~g}$ fresh weight each) were taken from short $(\leq 6 \mathrm{~cm})$ or tall $(>6 \mathrm{~cm})$ patches consisting of grass only (short grass: sg; tall grass: tg) or mixed vegetation including forbs and legumes (short mixed: sm; tall mixed: tm). In May 2007, HPS were collected on 10 permanent subplots per plot that were established for vegetation surveys and analysed per subplot. Thus, in 2007 it was possible to investigate different spatial aggregations of plant isotopic data (per subplot, per plot). The $\mathrm{CSH}$ of the vegetation was recorded at the time of sampling. For stable isotope analyses, vegetation samples were dried at $60^{\circ} \mathrm{C}$ and ground $(0.25 \mathrm{~mm})$.

Switch hair samples were plucked from two core animals per plot in July and October 2006, again from one of these animals per plot in January 2007 to check for effects of the diet shift from pasture to stable and thus the time needed between a feeding event and its visibility in the hair, and from two core animals per plot in September 2007 and prepared for stable isotope analysis according to Schwertl et al. (2003, 2005). Several hair segments of $1 \mathrm{~cm}$ length each taken along the sampled hairs were analysed, resulting in monthly values for ${ }^{15} \mathrm{~N}$ in cattle switch hair.

The isotopic analyses and determination of $\mathrm{N}$ concentrations of samples from 2006 were carried out with an isotope ratio mass spectrometer Finnigan MAT 251 (IRMS; Finnigan, Bremen, Germany), linked with a Conflo II-Interface (Thermo-Finnigan, Bremen, Germany) to an elemental analyser NA1500 (Carlo Erba Instruments, Milano, Italy). Samples from 2007 were analysed with a Delta Plus IRMS linked with a Conflo III-Interface (Finnigan MAT, Bremen, Germany) to an elemental analyser NA1110 (Carlo Erba Instruments, Milano, Italy). As reference gas, $\mathrm{N}_{2}$ was used, which was calibrated against the reference substances N1 and N2 (IAEA, Vienna). Acetanilide was used as internal standard. Values are reported in $\delta^{15} \mathrm{~N}$ notation (\%o, standard $=$ atmospheric air):

$$
\begin{gathered}
\delta^{15} \mathrm{~N}(\% \mathrm{oo})= \\
\text { with } \mathrm{R}={ }^{15} \mathrm{~N} /{ }^{14} \mathrm{~N}
\end{gathered}
$$

The reproducibility of both IRMS systems is better than $\pm 0.2 \%$ for $\delta^{15} \mathrm{~N}$.

Soil surface balances

In the following, first the data acquisition and calculation of the whole plot balances will be explained, then that of the split balances. Next to the balances for the years of sampling, 2006 and 2007 , longer term averages were also computed for both the whole plot balance and that for areas without dung pats. The starting year of the experiment, 2002, was discarded from the calculations of long-term averages. Unfortunately, no data was available for 2005. 
Whole plot balances

We considered the following inputs to the system: atmospheric deposition, N-fixation, and the animals' excreta. Mineral fertiliser application took place neither prior to nor during the experiment. Sedimentation or run-on of soil was considered negligible. The main output was the herbage intake of the animals. Residues were not considered as output, since no mowing took place at the end of the grazing season. Preliminary balances taking into account the difference in nutrients contained in residues between the end of a grazing season and the beginning of the next one did not differ significantly from those calculated without residues.

Monthly atmospheric deposition data was received from the sampling station of the 'Lower Saxony Water Management, Coastal Defence and Nature Conservation Agency' (NLWKN) in the Solling area (part of a network of long-term deposition sampling stations in Lower Saxony, Germany). For N fixation, we used the method after Weissbach (1995), where N fixation is determined from the dry matter yield of legumes and the amount of fertiliser applied. As no fertiliser was applied in our case, we only considered the $\mathrm{N}$ return with excreta, assuming for the calculation an even spread over the area. The dry matter yield of legumes was derived from the total dry matter yield and the surface cover of legumes assessed twice a year in botanical relevés on ten permanent subplots $\left(1 \mathrm{~m}^{2}\right.$ each $)$ per plot. The animals' $\mathrm{N}$ excretion was calculated as a percentage of their $\mathrm{N}$ intake (determined as explained below). It was expected that $90 \%$ of the $\mathrm{N}$ intake was excreted again (Whitehead 1995).

Herbage intake was calculated as the quotient of the animals' energy requirement and the energy supplied by herbage (Baker 2004). The energy requirement was defined following the procedure described by Baker (2004), assuming that the animals walked 3,000 horizontal and 10 vertical meters, stood for $14 \mathrm{~h}$ and made 9 positional changes per day. These assumptions were based on the plot sizes and slopes and on data by Baker (2004). As input to the calculation, mean live weight and live-weight changes of the animals due to growth (2002 to 2005) or pregnancy (2006 and 2007) were needed. To this end, the live weight of the animals was measured manually at the start and end of each grazing season and every 3 weeks in between using an automatic rotational weighing system linked to the watering places. The energy supplied by herbage $\left(E_{h}\right.$, in MJ metabolisable energy (ME) per kg dry matter) was calculated following an empirical equation suggested by Schmidt et al. (2004):

$$
\begin{aligned}
\mathrm{E}_{\mathrm{h}}(\mathrm{ME})= & 0.1520 \cdot \mathrm{DOM}_{\mathrm{D}}[\%]-0.0029 \\
& \cdot \operatorname{DungXA}[\mathrm{g} / \mathrm{kg}]-0.46
\end{aligned}
$$

where $\mathrm{DOM}_{\mathrm{D}}$ is the digestibility of herbage organic matter and DungXA the crude ash content of the faeces. Once a month, fresh faeces were sampled, dried at $70^{\circ} \mathrm{C}$, ground and analysed for $\mathrm{N}(\mathrm{CN}$ analyser) and DungXA (combustion at $550^{\circ} \mathrm{C}$ ). $\mathrm{DOM}_{\mathrm{D}}$ was derived from the $\mathrm{N}$ content of the faeces according to the faecal nitrogen method developed by Schmidt et al. (1999).

$\mathrm{N}$ output from the soil by grazing was calculated as the product of herbage intake and the $\mathrm{N}$ content of the herbage. For the latter, handpluck samples of the vegetation were taken five to six times per grazing season, dried at $60^{\circ} \mathrm{C}$, ground to pass a mesh of $1-\mathrm{mm}$ pore size and analysed for $\mathrm{N}$ content with nearinfrared reflectance spectroscopy according to Kesting et al. (2009), transforming values for crude protein into $\mathrm{N}$ content by dividing with a factor of 6.25 .

\section{Split balances}

Split nutrient balances were calculated for four different areas per plot: the area affected by dung pats, that affected by urine, the grazed area that did not receive nutrients from excreta, and the total area not affected by dung pats (i.e. balance urine + grazed). Following earlier observations (Bao et al. 1998; Longhurst et al. 2000), it was assumed that the area affected by faeces was not grazed in the year of faecal deposition, but the area affected by urine was grazed normally. Especially on the extensive treatments, the pasture area not affected by dung pats was not grazed uniformly, but subject to feeding preferences that could not be taken into account in the balances.

The size of the area affected by urine and faeces, respectively, was derived from the number of urinations or defecations per animal and day, the area of one urine or dung patch (Table 1), and the animal 
grazing days on the plots. Thus, these areas were assumed to be covered by a single layer of dung or urine. The area covered by dung was calculated to be $2.4,1.4$ and $0.9 \%$, that covered by urine $6.0,3.6$ and $2.3 \%$ of the total area for MC, LC and VLC in 2006, respectively. We called the area supposedly not affected by excreta 'grazed', notwithstanding that the urine-affected area was grazed as well.

For each area, nutrient balances were calculated as described above, with the appropriate inputs and outputs. The urine $\mathrm{N}$ excretion $\left(\mathrm{N}_{\text {urine }}, \mathrm{kg} \mathrm{ha}^{-1} \mathrm{a}^{-1}\right)$ was estimated with a polynomial regression (Whitehead 1995) of the animals' $\mathrm{N}$ intake $\left(\mathrm{N}_{\text {intake }}\left[\mathrm{kg} \mathrm{ha}^{-1}\right.\right.$ $\left.\mathrm{a}^{-1}\right]$ ), calculated from their herbage intake as outlined above and the fraction of $\mathrm{N}$ in herbage $\left(\mathrm{N}_{\text {herbage }}[\%]\right)$ :

$\mathrm{N}_{\text {urine }}=\mathrm{N}_{\text {intake }}\left(-4 \cdot\left(\mathrm{N}_{\text {herbage }}\right)^{2}+36 \cdot \mathrm{N}_{\text {herbage }}\right) / 100$

$\mathrm{N}$ in dung has been reported to be 6-7 $\mathrm{g} \mathrm{N}$ per $\mathrm{kg}$ dry matter intake (Schmidt et al. 1999). The sum of the thus derived $\mathrm{N}$ in dung and $\mathrm{N}$ in urine correlated well with the total calculated $\mathrm{N}$ excretion of the animals $\left(r^{2}=0.99\right.$ for data from 2006 and 2007).

\section{Statistics}

Treatments were set up in a randomised block design with three replicates. Statistical analyses were carried out with Statistica 9.0. In normally distributed data (Kolmogorov-Smirnov test), differences between treatments were investigated using analysis of variance $(\alpha=0.05)$ with treatment and year as factors after testing for differences between blocks. In case the variances were inhomogeneous (Levene's test),

Table 1 Number of urinations and defecations per animal and day, and area affected by one urination or defecation event

\begin{tabular}{lrll}
\hline & Number & Area $\left(\mathrm{m}^{2}\right)$ & Reference \\
\hline Urinations & $\mathbf{8}$ & $\mathbf{0 . 1 6}$ & (König 2002) \\
& 12 & 0.49 & (König 2002) \\
& 12 & 0.3 & (McGechan and Topp 2004) \\
& 12 & 0.68 & (McGechan and Topp 2004) \\
Defecations & $\mathbf{1 0}$ & $\mathbf{0 . 0 5}$ & (König 2002) \\
& 16 & 0.09 & (König 2002) \\
& 12 & 0.05 & (McGechan and Topp 2004)
\end{tabular}

Values shown in bold print were used for calculations the data was log-transformed before analyses. The $\mathrm{LSD}_{0.05}$ test was used for multiple comparisons between means. If the data was not normally distributed, the Kruskal-Wallis test was used to analyse differences $(\alpha=0.05)$, with the SchaichHamerle test as a post hoc test. Pearson correlation coefficients were used to calculate correlations between variables $(\alpha=0.05)$.

\section{Results}

Isotopic values

The three stocking rates had no significant influence on the $\delta^{15} \mathrm{~N}$ values of soil samples taken in May or July 2006 ( $P=0.41$; Fig. 1a). $\delta^{15} \mathrm{~N}$ values of soil samples ranged for all treatments from 3.9 to $5.6 \%$. Treatment MC showed a slight trend to more enriched $\delta^{15} \mathrm{~N}$ values compared to the other treatments. There were no significant differences between the two sampling dates $(P=0.051)$.

The $\delta^{15} \mathrm{~N}$ values differed significantly among handpluck samples in 2006: Pure grass samples were most enriched $(1.72 \pm 0.56 \%$ and $1.60 \pm 0.59 \%$ for $\mathrm{sg}$ and $\mathrm{tg}$, respectively), short mixed samples most depleted $(0.09 \pm 0.60 \%)$, and tall mixed samples intermediate, but significantly different from all others $(1.04 \pm 0.46 \%, \quad P<0.001)$. There were, however, no differences in $\delta^{15} \mathrm{~N}$ among HPS of different treatments or different years $(P=0.22$ for treatments and 0.32 for years; Fig. $1 b$ ). In both years, there was a trend to more depleted values in LC.

For cattle tail switch hair samples, there were seasonal variations in $\delta^{15} \mathrm{~N}$ values between the time the cattle were on the field and that spent in the stable (data not shown), but no significant differences among grazing treatments $(P=0.24$; Fig. 1c). Values ranged from 4.3 to $7.8 \%$.

\section{Balances}

Despite the different grazing intensities, the balance results were surprisingly similar between treatments. Still, there were significant differences between treatments and years (Table 2). For the soil surface balances of the whole plot, surpluses were larger in 2006 than in 2007 and larger on the intensive treatment MC than on the others, especially in 2006. The 


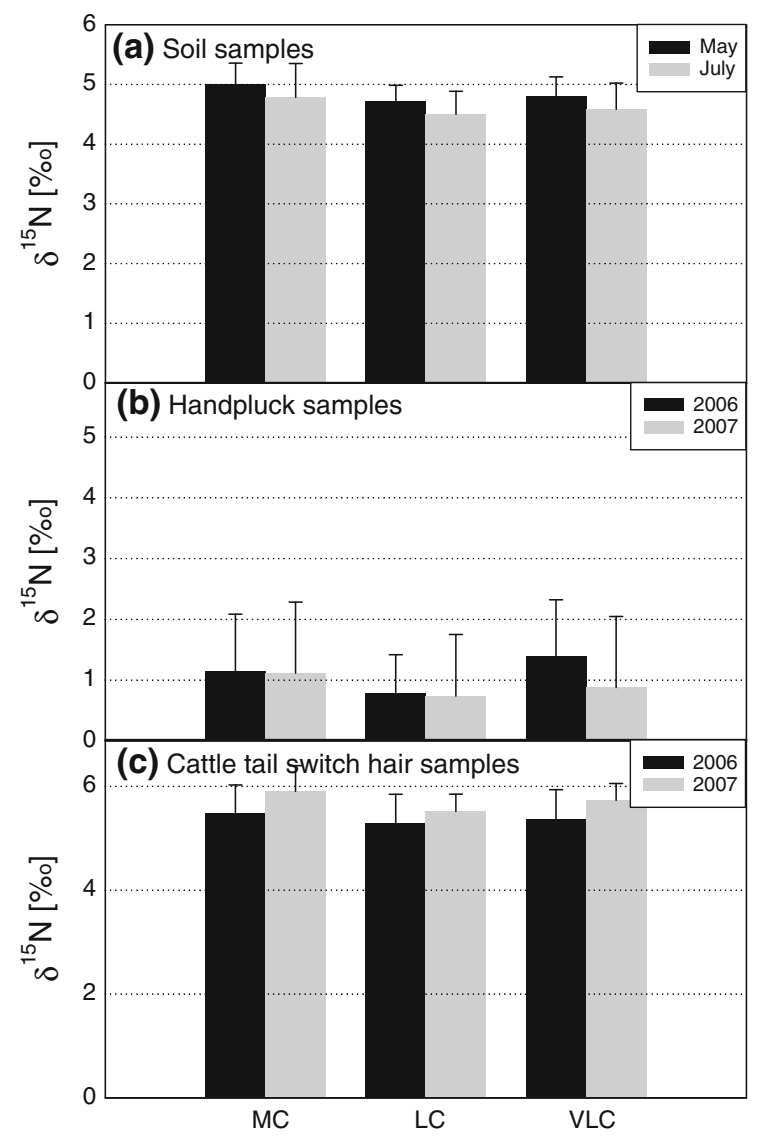

Fig. $1 \delta^{15} \mathrm{~N}$ values of soil, plant and cattle tail switch hair samples for the three treatments differing in grazing intensity ( $M C$ : moderate stocking, $L C$ : lenient stocking, $V L C$ : very lenient stocking). Shown are means per sampling date for soil, which was only sampled in $2006(n=9)$ and means per year for hair $(n=24$ in 2006 and 6 in 2007) and plant samples $(n=12$ in 2006 and 30 in 2007). Shown are means and standard deviations

interaction between treatments and years was not significant. The balances for areas affected by dung pats or by urine patches were much more positive than those for the whole plot area. Those for dung pats were significantly different among treatments and years and there was an interaction between both factors. This was largely due to smaller surpluses on treatment MC in 2007 , caused by smaller pasture performance and herbage intake (and therefore excretion) of the animals on these plots. Balances for areas affected by urine varied between years, but not among treatments. The balance results for areas that were grazed, but not affected by excreta, were negative. Here, there were significant differences among treatments, with deficits being larger in treatment MC. Differences between years were not significant.

The balances for the total area not affected by dung pats (urine + grazed) all showed moderate surpluses. There were significant differences between years, with larger surpluses in 2007. Differences among treatments or interactions of year and treatment were not significant. There were no significant differences among treatments, years or interactions thereof for several-year averages of these balances.

Balances and isotopic values

Soil isotopic values showed significant positive correlations with balances calculated for areas with dung pats and those with urine patches, and significant negative correlations with balances for grazed areas not receiving any nutrient input from excreta and for areas affected by urine patches and grazing (Table 3). The coefficients of determination were between 0.15 and 0.35 for the significant correlations. The $\delta^{15} \mathrm{~N}$ values of vegetation were only significantly correlated with the four-year mean of the balances for areas not affected by dung pats. Cattle tail switch hair $\delta^{15} \mathrm{~N}$ values were not significantly correlated with any of the $\mathrm{N}$ balances.

\section{Discussion}

In this study, we analysed correlations between ${ }^{15} \mathrm{~N}$ signatures of soil, vegetation and cattle tail switch hair samples, respectively, and whole plot or split balances for $\mathrm{N}$ in heterogeneous permanent pasture systems. In the following, we will first discuss the stable isotope data, the balance results and then go on to analyse (missing) correlations between both.

Isotopic values

The $\delta^{15} \mathrm{~N}$ values of soil samples measured (Fig. 1a) were in line with values reported in the literature (Bedard-Haughn et al. 2003; Kerley and Jarvis 1997). The lack of significant differences among treatments might be due to the sampling of total soil N. This pool turns over slowly and it takes long before its ${ }^{15} \mathrm{~N}$ signature changes (Högberg 1997). Thus, Dijkstra et al. (2006) found no change in total soil ${ }^{15} \mathrm{~N}$ along a cattle manure gradient, despite differences in soil $\mathrm{N}$ 
Table 2 Nitrogen soil surface balances for the whole plot (plot balance) or for areas affected by dung (dung pats), urine (urine patches), grazing without $\mathrm{N}$ input through the animals (grazed areas) or the total area not affected by dung pats (urine + grazed). Additionally, results for the latter balance of the three years before measurement (three-year mean urine + grazed) or of all years since 2003 (mean urine + grazed since 2003) were averaged. All values are in $\mathrm{kg} \mathrm{N}^{-1} \mathrm{a}^{-1}$ (mean \pm standard deviation). The second part of the table shows $P$ values of ANOVA analyses $(\alpha=0.05$; Trtmt Treatment, i.e., $M C$ moderate stocking, $L C$ lenient stocking, $V L C$ very lenient stocking)

\begin{tabular}{|c|c|c|c|c|c|c|c|}
\hline & Plot balance & Dung pats & Urine patches & Grazed areas & $\begin{array}{l}\text { Urine + } \\
\text { grazed }\end{array}$ & $\begin{array}{l}\text { Three-year } \\
\text { mean urine }+ \\
\text { grazed }\end{array}$ & $\begin{array}{l}\text { Mean urine + } \\
\text { grazed } \\
\text { since } 2003\end{array}$ \\
\hline \multicolumn{8}{|l|}{2006} \\
\hline $\mathrm{MC}$ & $39.1 \pm 8.0$ & $1,317.8 \pm 65.4$ & $1,245.2 \pm 164.7$ & $-78.2 \pm 29.6$ & $2.7 \pm 11.8$ & $10.0 \pm 2.2$ & $10.0 \pm 2.2$ \\
\hline $\mathrm{LC}$ & $25.5 \pm 1.0$ & $1,304.3 \pm 37.6$ & $950.1 \pm 35.6$ & $-35.7 \pm 5.2$ & $0.3 \pm 2.7$ & $14.6 \pm 8.2$ & $14.6 \pm 8.2$ \\
\hline VLC & $25.2 \pm 1.0$ & $1,284.2 \pm 24.2$ & $873.7 \pm 77.7$ & $-11.1 \pm 2.2$ & $9.2 \pm 0.6$ & $10.1 \pm 7.3$ & $10.1 \pm 7.3$ \\
\hline \multicolumn{8}{|l|}{2007} \\
\hline $\mathrm{MC}$ & $25.00 \pm 8.2$ & $1,037.2 \pm 111.1$ & $1,711.0 \pm 167.4$ & $-84.6 \pm 25.9$ & $14.2 \pm 10.2$ & $7.7 \pm 2.8$ & $11.1 \pm 1.7$ \\
\hline $\mathrm{LC}$ & $23.0 \pm 2.9$ & $1,356.5 \pm 14.5$ & $2,460.3 \pm 893.2$ & $-56.2 \pm 32.4$ & $17.3 \pm 11.8$ & $11.2 \pm 9.6$ & $15.2 \pm 9.1$ \\
\hline VLC & $16.0 \pm 3.5$ & $1,325.1 \pm 50.0$ & $1,962.4 \pm 66.2$ & $-30.7 \pm 4.4$ & $7.7 \pm 3.6$ & $4.7 \pm 3.3$ & $9.5 \pm 5.8$ \\
\hline Trtmt & 0.005 & 0.002 & 0.412 & 0.001 & 0.996 & 0.325 & 0.360 \\
\hline Year & 0.002 & 0.046 & 0.001 & 0.143 & 0.038 & 0.237 & 0.900 \\
\hline Trtmt $\times$ Year & 0.302 & 0.001 & 0.096 & 0.811 & 0.177 & 0.907 & 0.973 \\
\hline
\end{tabular}

concentrations of approximately 1 to $4 \mathrm{mg} \mathrm{N} \mathrm{g}_{\text {soil }}^{-1}$. An analysis of more labile $\mathrm{N}$ pools, like soil mineral $\mathrm{N}$, might offer a better potential to detect differences among treatments.

Also in the vegetation samples (Fig. 1b), the $\mathrm{N}$ isotopic values were similar to literature values (e.g. Temperton et al. 2007). The $\delta^{15} \mathrm{~N}$ values were significantly larger in pure grass than in mixed samples. This is most likely due to $\mathrm{N}$ fixation by legumes in mixed samples, which yields a lower isotopic value than $\mathrm{N}$ from soil sources (Högberg 1997; Shearer and Kohl 1986). Temperton et al. (2007) have shown that legumes may also lead to lower ${ }^{15} \mathrm{~N}$ signatures of neighbouring species, probably mainly through reduced competition for soil $\mathrm{N}$. The difference between tall and short mixed vegetation was probably caused by the smaller relative biomass of legumes, mainly Trifolium repens, and thus smaller impact in tall vegetation patches.

The $\delta^{15} \mathrm{~N}$ values of cattle tail switch hair samples (Fig. 1c) were within the range of 1.7-9\%o found by Schwertl et al. (2003). For summer feeding on a green pasture, Schwertl et al. (2003) reported $\delta^{15} \mathrm{~N}$ values of approximately $5.7 \%$, very similar to the $5.5 \pm 0.5 \%$ we measured. The seasonal variation found was due to different feeding of the animals on the pastures and in the stable (Schwertl et al. 2003).
Balance results

Plot scale balances indicated the largest surpluses on plots with most animals (MC, Table 2). The balances were dominated by the difference between $\mathrm{N}$ intake and output of the animals and the $\mathrm{N}$ fixed by legumes. Due to a larger cover of the main legume occurring on the plots, Trifolium repens, $\mathrm{N}$ fixation was always larger in $\mathrm{MC}$ than in the less intensively grazed treatments. This was probably related to the shorter vegetation height of $\mathrm{MC}$ and is reflected by the significant correlation we found between compressed sward height and the vegetation's ${ }^{15} \mathrm{~N}$ : the smaller the vegetation, the less enriched in ${ }^{15} \mathrm{~N}(P=0.001$, $\left.r^{2}=0.13, \mathrm{~m}=1.25\right)$, indicating a larger influence of $\mathrm{N}$ fixation. As the amount of $\mathrm{N}$ fixed per treatment was larger than the difference between $\mathrm{N}$ intake and output of the animals, $\mathrm{N}$ fixation controlled the balance results, leading to the large surpluses on MC.

Of course, nutrient inputs with excreta dominated the patches affected by them and accordingly the split balances for areas with dung pats or urine patches, while the balances for grazed areas were controlled by the $\mathrm{N}$ intake of the animals (Table 2). The overall values calculated are in line with literature values on $\mathrm{N}$ inputs with excreta (e.g. Virkajärvi et al. 2010; Wachendorf et al. 2008). The balances for areas 
Table 3 Correlations between $\delta^{15} \mathrm{~N}$ in soil $(\mathrm{n}=27)$, plant (HPS hand-pluck sample; $\mathrm{n}=18$ ) or cattle tail switch hair samples $(\mathrm{n}=18)$ and nitrogen balance results

\begin{tabular}{|c|c|c|c|c|}
\hline & $\mathrm{m}$ & $\mathrm{b}$ & $r^{2}$ & $P$ \\
\hline \multicolumn{5}{|l|}{ Soil } \\
\hline Plot balance & 0.002 & 4.66 & 0.00 & 0.786 \\
\hline Dung pats & 0.003 & 0.40 & 0.17 & 0.035 \\
\hline Urine patches & 0.001 & 3.65 & 0.35 & 0.001 \\
\hline Grazed areas & -0.006 & 4.50 & 0.29 & 0.004 \\
\hline Urine + grazed & -0.018 & 4.81 & 0.15 & 0.047 \\
\hline $\begin{array}{l}\text { Three-year mean } \\
\text { urine }+ \text { grazed* }\end{array}$ & -0.012 & 4.87 & 0.04 & 0.307 \\
\hline \multicolumn{5}{|l|}{ HPS } \\
\hline Plot balance & 0.001 & 0.99 & 0.00 & 0.966 \\
\hline Dung pats & -0.000 & 1.05 & 0.00 & 0.973 \\
\hline Urine patches & -0.000 & 1.28 & 0.07 & 0.273 \\
\hline Grazed areas & -0.002 & 0.92 & 0.02 & 0.609 \\
\hline Urine + grazed & -0.015 & 1.13 & 0.10 & 0.209 \\
\hline Three-year mean urine + grazed & -0.027 & 1.27 & 0.15 & 0.115 \\
\hline Mean urine + grazed since 2003 & -0.035 & 1.42 & 0.23 & 0.043 \\
\hline \multicolumn{5}{|l|}{ Cattle tail switch hair } \\
\hline Plot balance & -0.016 & 5.94 & 0.21 & 0.058 \\
\hline Dung pats & 0.000 & 5.36 & 0.00 & 0.804 \\
\hline Urine patches & 0.000 & 5.26 & 0.19 & 0.073 \\
\hline Grazed areas & -0.002 & 5.46 & 0.04 & 0.446 \\
\hline Urine + grazed & -0.001 & 5.55 & 0.00 & 0.926 \\
\hline Three-year mean urine + grazed & -0.020 & 5.74 & 0.19 & 0.074 \\
\hline Mean urine + grazed since 2003 & -0.015 & 5.72 & 0.09 & 0.226 \\
\hline
\end{tabular}

Shown are slope $(\mathrm{m})$, intercept $(\mathrm{b})$, coefficient of determination $\left(r^{2}\right)$ and $P$ values $(P)$. Balance results are shown and titles explained in Table 2

* As soil was only sampled in 2006 , the results of the ' 3 -year mean urine + grazed' was identical to that of the 'mean urine + grazed since 2003'

without cow pats (urine + grazed) showed more similarities between MC and VLC than between LC and VLC. This was due to the relation between herbage intake of the animals as output and $\mathrm{N}$ fixation as input of $\mathrm{N}$ as discussed above.

Balances and isotopic values

With one exception, only soil isotopic values showed significant correlations with balance results. The main reason was probably the small difference among $\mathrm{N}$ budgets of the different treatments. Other potential reasons that will be discussed briefly are the different sampling schemes as well as potential influences on vegetation and hair samples that might impact the correlations.

Soil was only sampled in 2006, not as the other potential indicators both in 2006 and 2007. However, correlations for vegetation and hair samples were not improved if the data was analysed per year (data not shown). Thus, it is unlikely that the better correlations found for soil samples are due to the different temporal scale.

Which impact did spatial scales of sampling have? Composite soil samples were taken along plot transects. Vegetation sampling was conducted in slightly different ways in both years, but the samples were in both cases taken in a less aggregated way than soil samples. However, the vegetation data was aggregated later by calculating plot-scale means, which did not improve the correlations with balances compared to the non-aggregated data. The isotopic signature of the cattle switch hair is a result of composite sampling done by the animals. Thus, this data is on a similar scale as that of the soil samples. Apparently, the spatial scale of sampling was not the main factor determining the goodness of the correlations.

The soil $\mathrm{N}$ pool is directly influenced by the inputs and outputs considered in the $\mathrm{N}$ surface balances. Thus, $\mathrm{N}$ surpluses should have a more immediate effect on soil values than on the vegetation or the herbivores. Vegetation values depend on the soil mineral $\mathrm{N}$ values, but can also be influenced by $\mathrm{N}$ fixation, i.e. derive $\mathrm{N}$ from two distinct pools. For the vegetation not affected by excreta patches, $\mathrm{N}$ fixation can be a main source of $\mathrm{N}$, as discussed above. In previous experiments, it has been shown that $\mathrm{N}$ fixed by legumes may be transferred to neighbouring vegetation and influence ${ }^{15} \mathrm{~N}$ values there as well (Høgh-Jensen and Schjoerring 2000; Pate et al. 1994; Temperton et al. 2007). Thus, the isotopic signature of legumes as well as of the total vegetation would depend less on that of soil mineral $\mathrm{N}$ and more on the atmospheric $\mathrm{N}$ pool. Only with very large soil mineral N concentrations (Ledgard and Steele 1992) or limiting phosphorus concentrations (Almeida et al. 2000), the amount of $\mathrm{N}$ fixed by legumes would be decreased and thus the vegetation's isotopic composition influenced more by soil values. On pastures such as the ones considered here, large $\mathrm{N}$ concentrations limiting $\mathrm{N}$ fixation occur locally at excreta 
patches (Ball et al. 1979). In intensive dairy farming, urine affecting $40 \%$ of the pasture area has been estimated to decrease $\mathrm{N}$ fixation by at least $10 \%$ annually (Ledgard et al. 1982). In the extensively used pastures considered here, we calculated the area affected by urine to be less than $6 \%$ of the total pasture area and that affected by dung to be less than $2.5 \%$, suggesting that the effect on $\mathrm{N}$ fixation would be quite small, possibly leading to the smaller dependence of vegetation on soil values.

With an average over 2006 and 2007 of $24.5 \pm$ $1.9 \mathrm{mg} \mathrm{P} \mathrm{kg}^{-1}$ dry soil (calcium acetate lactate extraction), the $\mathrm{P}$ concentrations were quite small and might have impacted $\mathrm{N}$ fixation. However, as discussed above, $\mathrm{N}$ fixation contributed to the herbage $\mathrm{N}$, especially in patches of short vegetation, causing $\delta^{15} \mathrm{~N}$ values close to zero $(-0.14 \pm 0.58,0.01 \pm 0.46$ and $0.38 \pm 0.81$ in samples of short mixed vegetation on MC, LC and VLC, respectively, in July 2006). On top of $\mathrm{N}$ fixation, vegetation $\delta^{15} \mathrm{~N}$ values may also be influenced by other factors such as the physiological stage of the vegetation (Evans 2001), which would again not be related to $\mathrm{N}$ budgets.

The ${ }^{15} \mathrm{~N}$ signature of the cattle tail switch hairs was probably influenced by selective feeding. Behaviour studies carried out in the experiment showed that animals preferred to feed on short mixed vegetation, supplemented by short pure grass in the mornings and tall mixed vegetation in the afternoon (Röver 2006). With increased $\mathrm{N}$ fixation by short mixed vegetation (see above), animals feeding preferentially on such patches would take up less soil-derived $\mathrm{N}$, but more $\mathrm{N}$ derived from air. However, this latter pool is not correlated to local soil surface $\mathrm{N}$ balances. This might explain the missing correlation between cattle hair values and balance results.

Although the correlations found between balances and soil isotopic values were better than the other correlations, the soil isotopic values also only explained between 15 and $35 \%$ of the variation in $\mathrm{N}$ balances. This might have been related to small overall $\mathrm{N}$ losses and small differences between $\mathrm{N}$ balances. Although $\mathrm{N}$ losses per dung and especially urine patch can be substantial (Wachendorf et al. 2005, 2008; Yamulki et al. 2000), losses integrated over the plot area would still be expected to be small as 92 to $97 \%$ of the plot areas had negative $\mathrm{N}$ balances (grazed areas, Table 2). Here, the $\mathrm{N}$ cycle would be relatively tight with active pools in soil and vegetation of similar sizes and a limited potential for fractionations (Robinson 2001). In such a system, isotopic values of soil, vegetation or cattle hair samples do not seem to be reliable indicators of whole plot or split $\mathrm{N}$ balances.

\section{Conclusions}

Even the best indicator of balances, soil ${ }^{15} \mathrm{~N}$ values, only explained up to $35 \%$ of the variation. Thus, it does not seem possible to use any of the considered variables as indicators of $\mathrm{N}$ balances in such a heterogeneous pasture system, where differences in $\mathrm{N}$ balances among treatments were very small. Whether ${ }^{15} \mathrm{~N}$ signatures are potential indicators of $\mathrm{N}$ balances in grazing systems differing more in the intensity of use and thus in $\mathrm{N}$ balances remains to be investigated.

Acknowledgments We thank Barbara Hohlmann (Goettingen University) for skilful sampling and analyses, Arne Oppermann and colleagues from the experimental farm of Goettingen University at Relliehausen for assistance with all theoretical and practical questions concerning the animals, Jens Dyckmans and colleagues from the Competence Centre Stable Isotopes (KOSI) of Goettingen University for analysis of the isotope samples, and Karl Auerswald (Technical University Munich) for discussion of a preliminary dataset.

Open Access This article is distributed under the terms of the Creative Commons Attribution Noncommercial License which permits any noncommercial use, distribution, and reproduction in any medium, provided the original author(s) and source are credited.

\section{References}

Almeida JF, Hartwig UA, Frehner M, Nosberger J, Luscher A (2000) Evidence that $\mathrm{P}$ deficiency induces $\mathrm{N}$ feedback regulation of symbiotic $\mathrm{N}_{2}$ fixation in white clover (Trifolium repens L.). J Exp Botany 51:1289-1297

Auerswald K, Mayer F, Schnyder H (2010) Coupling of spatial and temporal pattern of cattle excreta patches on a low intensity pasture. Nutr Cycl Agroecosyst 88:275-288

Baker RD (2004) Estimating herbage intake from animal performance. In: Penning PD (ed) Herbage intake handbook. British Grassland Society, Reading, pp 95-120

Ball R, Keeney DR, Theobald PW, Nes P (1979) Nitrogen balance in urine-affected areas of a New Zealand pasture. Agronomy J 71:309-314

Bao J, Giller PS, Stakelum G (1998) Selective grazing by dairy cows in the presence of dung and the defoliation of tall grass dung patches. Animal Sci 66:65-73

Bedard-Haughn A, van Groenigen JW, van Kessel C (2003) Tracing ${ }^{15} \mathrm{~N}$ through landscapes: potential uses and precautions. J Hydrol 272:175-190 
Bouwman AF (1990) Exchange of greenhouse gases between terrestrial ecosystems and the atmosphere. In: Bouwman $\mathrm{AF}$ (ed) International conference soils and the greenhouse effect. Wiley, Chichester, pp 61-127

Castle ME (1976) A simple disc instrument for estimating herbage yield. J British Grassland Soc 31:37-40

Correll O, Isselstein J, Pavlu V (2003) Studying spatial and temporal dynamics of sward structure at low stocking densities: the use of an extended rising-plate-meter method. Grass Forage Sci 58:450-454

Decau ML, Simon JC, Jacquet A (2004) Nitrate leaching under grassland as affected by mineral nitrogen fertilization and cattle urine. J Environ Qual 33:637-644

Dijkstra P, Menyailo OV, Doucett RR, Hart SC, Schwartz E, Hungate BA (2006) $\mathrm{C}$ and $\mathrm{N}$ availability affects the ${ }^{15} \mathrm{~N}$ natural abundance of the soil microbial biomass across a cattle manure gradient. Eur J Soil Sci 57:468-475

Evans RD (2001) Physiological mechanisms influencing plant nitrogen isotope composition. Trends Plant Sci 6:121-126

Frank AB, Tanaka DL, Hofmann L, Follett RF (1995) Soil carbon and nitrogen of Northern Great plains grasslands as influenced by long-term grazing. J Range Manag 48:470-474

Franzluebbers AJ, Stuedemann JA, Schomberg HH (2000) Spatial distribution of soil carbon and nitrogen pools under grazed Tall Fescue. Soil Sci Soc Am J 64:635-639

Högberg P (1997) ${ }^{15} \mathrm{~N}$ natural abundance in soil-plant systems. New Phytol 137:179-203

Høgh-Jensen H, Schjoerring JK (2000) Below-ground nitrogen transfer between different grassland species: direct quantification by ${ }^{15} \mathrm{~N}$ leaf feeding compared with indirect dilution of soil ${ }^{15} \mathrm{~N}$. Plant Soil 227:171-183

IPCC (2001) Climate change 2001: the scientific basis. Contribution of working group I to the third assessment report of the intergovernmental panel on climate change. Cambridge University Press, Cambridge, United Kingdom and New York, NY, USA

Isselstein J, Griffith BA, Pradel P, Venerus S (2007) Effects of livestock breed and grazing intensity on biodiversity and production in grazing systems. 1. Nutritive value of herbage and livestock performance. Grass Forage Sci 62:145-158

Kerley SJ, Jarvis SC (1997) Variation in ${ }^{15} \mathrm{~N}$ natural abundance of soil, humic fractions and plant materials in a disturbed and an undisturbed grassland. Biol Fer Soil 24:147-152

Kesting S, Wrage N, Isselstein J (2009) Herbage mass and nutritive value of herbage of extensively managed temperate grasslands along a gradient of shrub encroachment. Grass Forage Sci 64:246-254

König HP (2002) Stickstoffumsatz und $\mathrm{N}_{\text {min }}$-Anreicherung auf Grünland während des Winters bei ganzjähriger Außenhaltung von Fleischrindern. Dissertation, University of Göttingen

Ledgard SF, Steele KW (1992) Biological nitrogen fixation in mixed legume/grass pastures. Plant Soil 141:137-153

Ledgard SF, Steele KW, Saunders WHM (1982) Effects of cow urine and its major constituents on pasture properties. NZ J Agric Res 25:61-68

Longhurst RD, O'Connor MB, Bremner K, Matthews L (2000) Animal constraints to pasture treated with farm dairy effluent: preference under grazing and issues of faecal contamination. NZ J Agric Res 43:501-507
McGechan MB, Topp CFE (2004) Modelling environmental impacts of deposition of excreted nitrogen by grazing dairy cows. Agric Ecosyst Environ 103:149-164

Neilson R et al (1998) Stable isotope natural abundances of soil, plants and soil invertebrates in an upland pasture. Soil Biol Biochem 30:1773-1782

Oenema O, Wrage N, Velthof G, van Groenigen JW, Dolfing J, Kuikman P (2005) Trends in global nitrous oxide emissions from animal production systems. Nutr Cycl Agroecosyst 72:51-65

Pate JS, Unkovich MJ, Armstrong EL, Sanford P (1994) Selection of reference plants for ${ }^{15} \mathrm{~N}$ natural-abundance assessment of $\mathrm{N}_{2}$ fixation by crop and pasture legumes in South-West Australia. Aust J Agric Res 45:133-147

Petersen RG, Lucas HL, Woodhouse J (1956) The distribution of excreta by freely grazing cattle and its effect on pasture fertility: II. Effect of returned excreta on the residual concentration of some fertilizer elements. Agronomy J 48:444-449

Robinson D (2001) $\delta^{15} \mathrm{~N}$ as an integrator of the nitrogen cycle. Trends Ecol Evol 16:153-162

Röver K-U (2006) Grazing behaviour and performance of beef cattle on grassland managed for biodiversity benefits. Dissertation, University of Göttingen

Saarijärvi K, Mattila PK, Virkajärvi P (2006) Ammonia volatilization from artificial dung and urine patches measured by the equilibrium concentration technique (JTI method). Atmos Environ 40:5137-5145

Sahin Demirbag N, Röver K-U, Wrage N, Hofmann M, Isselstein J (2009) Herbage growth rates on heterogeneous swards as influenced by sward-height classes. Grass Forage Sci 64:12-18

Schmidt L, Weissbach F, Hoppe T, Kuhla S (1999) Untersuchungen zur Verwendung der Kotstickstoff-Methode für die Schätzung des energetischen Futterwertes von Weidegras und zum Nachweis der selektiven Futteraufnahme auf der Weide. Landbauforschung Völkenrode 49: 123-135

Schmidt L, Hoppe T, Weissbach F (2004) Anwendung der Kotstickstoff- und der n-Alkan-Methode zur Ermittlung der Futter- und Energieaufnahme von Jungrindern auf der Weide. Landbauforschung Völkenrode 54:35-44

Schnyder H, Locher F, Auerswald K (2010) Nutrient redistribution by grazing cattle drives patterns of topsoil $\mathrm{N}$ and $\mathrm{P}$ stocks in a low-input pasture ecosystem. Nutr Cycl Agroecosyst 88:183-195

Schwertl M, Auerswald K, Schnyder H (2003) Reconstruction of the isotopic history of animal diets by hair segmental analysis. Rapid Commun Mass Spectrom 17:1312-1318

Schwertl M, Auerswald K, Schäufele R, Schnyder H (2005) Carbon and nitrogen stable isotope composition of cattle hair: ecological fingerprints of production systems? Agric Ecosyst Environ 109:153-165

Shearer G, Kohl DH (1986) $\mathrm{N}_{2}$-Fixation in field settings: estimations based on natural ${ }^{15} \mathrm{~N}$ abundance. Aust J Plant Physiol 13:699-756

Temperton V, Mwangi P, Scherer-Lorenzen M, Schmid B, Buchmann N (2007) Positive interactions between nitrogen-fixing legumes and four different neighbouring species in a biodiversity experiment. Oecologia 151:190205 
van Beek CL, Brouwer L, Oenema O (2003) The use of farmgate balances and soil surface balances as estimators for nitrogen leaching to surface water. Nutr Cycl Agroecosyst 67:233-244

Virkajärvi P, Maljanen M, Saarijärvi K, Haapala J, Martikainen PJ (2010) $\mathrm{N}_{2} \mathrm{O}$ emissions from boreal grass and grassclover pasture soils. Agric Ecosyst Environ 137:59-67

Vitousek PM, Shearer G, Kohl DH (1989) Foliar ${ }^{15} \mathrm{~N}$ natural abundance in Hawaiian rainforest: patterns and possible mechanisms. Oecologia 78:383-388

Wachendorf C, Taube F, Wachendorf M (2005) Nitrogen leaching from ${ }^{15} \mathrm{~N}$ labelled cow urine and dung applied to grassland on a sandy soil. Nutr Cycl Agroecosyst 73: 89-100

Wachendorf C, Lampe C, Taube F, Dittert K (2008) Nitrous oxide emissions and dynamics of soil nitrogen under ${ }^{15} \mathrm{~N}$ labeled cow urine and dung patches on a sandy grassland soil. J Plant Nutr Soil Sci 171:171-180

Wade MH, Peyraud JL, Lemaire G, Cameron EA (1989) The dynamics of daily area and depth of grazing and herbage intake of cows in a five day paddock system. In: 16th international grassland congress, Nice, pp 1111-1112

Watzka M, Buchgraber K, Wanek W (2006) Natural ${ }^{15} \mathrm{~N}$ abundance of plants and soils under different management practices in a montane grassland. Soil Biol Biochem 38: 1564-1576

Webster EA, Hopkins DW (1996) Nitrogen and oxygen isotope ratios of nitrous oxide emitted from soil and produced by nitrifying and denitrifying bacteria. Biol Fer Soils 22: 326-330

Weissbach F (1995) Über die Schätzung des Beitrags der symbiontischen $\mathrm{N}_{2}$-Fixierung durch Weißklee zur Stickstoffbilanz von Grünlandflächen. Landbauforschung Völkenrode 45:67-74

Whitehead DC (1995) Grassland nitrogen. CAB International, Oxon

Wittmer M, Auerswald K, Schönbach P, Bai Y, Schnyder H (2010) ${ }^{15} \mathrm{~N}$ fractionation between vegetation, soil, faeces and wool is not influenced by stocking rate. Plant Soil 1-9. doi:10.1007/s11104-010-0411-5

Yamulki S et al (2000) Effects of dung and urine amendments on the isotopic content of $\mathrm{N}_{2} \mathrm{O}$ released from grasslands. Rapid Commun Mass Spectrom 14:1356-1360

Yoshida $\mathrm{N}(1988){ }^{15} \mathrm{~N}$-depleted $\mathrm{N}_{2} \mathrm{O}$ as a product of nitrification. Nature 335:528-529 